
ПРИРОДНИЧО-МАТЕМАТИЧНИХ ДИСЦИПЛІН У ПЕРІОД КІНЦЯ 50 - ПОЧАТКУ 90-Х РР. ХХСТ.

3. Skrypnyk, S. V. (2011). Teoriia ta praktyka vprovadzhennia informatsiinokomunikatsiinykh tekhnolohii u zahalnoosvitnikh navchalnykh zakladakh. Obmin praktychnym dosvidom ta tekhnolohiiamy. Vymiriuvalna ta obchysliuvalna tekhnika $\mathrm{v}$ tekhnolohichnykh protsesakh [Theory and practice of introduction of information and communication technologies in general educational institutions. Exchange of practical experience and technologies. Measuring and computing equipment in technological processes]. International scientific and technical journal. Khmelnytskyi, no.1, 316 p. [in Ukrainian].

4. Tymoshchuk, N.M. \& Dovhan, L.I. (2011). Vykorystannia informatsiino-komunikatsiinykh zasobiv navchannia na zaniattiakh $\mathrm{z}$ inozemnoi movy $\mathrm{u}$ ahrarnykh VNZ [The use of information and communication tools in foreign language classes in agricultural universities]. Ministry of Agrarian Policy of Ukraine, Department of Agrarian Education, Science and Advisory, Scientific and Methodological Center for Agrarian Education; (Ed). T.D. Ishchenko and others. Kyiv, vol.22, 96 p. [in Ukrainian].

5. Hutorskoj, A. (2004). Praktikum po didaktike i sovremennym metodikam obuchenija [Workshop on didactics and modern teaching methods]. St. Petersburg, 541p. [in Russian].

6. Sukhobok, O. (2010). Psykholoho-pedahohichni aspekty zastosuvannia informatsiinokomunikatsiinykh tekhnolohii u protsesi profesiinoi pidhotovky maibutnikh uchyteliv fizychnoi kultury [Psychological and pedagogical aspects of the application of information and communication technologies in the process of professional training of future teachers of physical culture]. Pedagogy, psychology and medical and biological problems of physical education and sports: a scientific journal. Kharkiv, no.12, 182 p.[in Ukrainian].

Стаття надійшла до редакції 25.06.2021

УДК 373.5.016:5-047.37(073)

DOI:

Наталя Галицька, аспірантка, кафедри педагогіки й менеджменту освіти КВНЗ “Херсонська академія неперервної освіти”

\title{
ВПЛИВ САМОСТІЙНОЇ РОБОТИ УЧНІВ НА РОЗВИТОК ДОСЛІДНИЦЬКИХ УМІНЬ УЧНІВ НА УРОКАХ ПРИРОДНИЧО-МАТЕМАТИЧНИХ ДИСЦИПЛІН У ПЕРІОД КІНЦЯ 50 - ПОЧАТКУ 90-Х РР. ХХ СТ.
}

Інновачійні умови, в яких перебуває сучасний заклад середньої освіти, передбачає від здобувачів освіти все більше самостійної роботи. Самостійна робота, як система навчальної діяльності, кіния 50 - початку 90-х рр. ХХ ст. виступала пігрунтям для розвитку дослідницьких умінь учнів на уроках природничоматематичних дисциплін. Для поступового формування кожного компонента структури дослідницьких умінь: операчійно-базових, інформачійно-комунікативних, практично-технічних та узагалювально-оцінювальних умінь, самостійна робота функиіонувала в єдності з різними формами та методами навчання, що забезпечувала гармонійний світоглядний розвиток учня як особистості.

Ключові слова: урок; шкільна освіта; самостійна робота; досліднищькі уміння; освітнє середовище; природничо-математичні дисиипліни; природничо-математична компетентність.

Jim. 5.

Natalia Halytska, Postgraduate Student of the Pedagogy and Management of Education Department, Municipal Higher Education Institution "Kherson Academy of Continuing Education"

\section{THE INFLUENCE OF STUDENTS' INDEPENDENT WORK ON THE DEVELOPMENT OF STUDENTS' RESEARCH SKILLS IN THE LESSONS OF NATURALAND MATHEMATICAL DISCIPLINES IN THE PERIOD LATE 50'S - EARLY 90'S OF THE XX CENTURY}

The innovative conditions in which the modern secondary education institution is located provide more and more independent work for students. Independent work, as a system of active activity, in the late 50's - early 90's of the XX century served as a foundation for the development of research skills of students in the lessons of natural sciences and mathematics. In this historical period, independent work determined the development of students' cognitive abilities: observation, logical thinking, memory, creative activity. The organization of independent work was aimed at the development of student self-education. The relationship between the concepts of "activity" and "independence" was determined. For the gradual formation of each component of the structure of research skills 


\section{ВПЛИВ САМОСТІЙНОӦ РОБОТИ УЧНІВ НА РОЗВИТОК ДОСЛІНИЦЬКИХ УМІНЬ УЧНІВ НА УРОКАХ ПРИРОДНИЧО-МАТЕМАТИЧНИХ ДИСЦИПЛІН У ПЕРІОДКІНЦЯ 50 - ПОЧАТКУ 90-Х РР. ХХСТ.}

(operational-basic, information-communication skills, practical-technical and generalizing-evaluative skills), independent work functioned in unity with different forms and methods of teaching, providing a harmonious worldview of the student as a person.

In the first period (semantic and ideological, 1958 - 1964 of the XX century) of the development of research skills, independent work was characterized by activation in the plane of development of practical skills. In the second period (educational and polytechnic, 1965 - 1972 of the XX century) the development of research skills is introduced independent work with the textbook, but at the same time there is an overload of students. In the third period (transformational research, 1973 - 1993 of the XX century), the development of research skills identified two subperiods. In the first subperiod "intellectual search" (1973-1983), independent work played a major role in the formation of intellectual skills (in terms of the theory of the gradual formation of mental actions); in the second subperiod "interdisciplinary research" (1984 - 1993) independent work with the textbook is widely used in the teaching of subjects, which is reflected in the curriculum. Varieties of independent works are determined: algorithmic, variable, creative, aimed at search work. There is an attempt to classify methods, including problem-solving method (separated from research); self-search method; the research method goes from search to productive-cognitive. Research skills in the period of transformation are supplemented by interdisciplinary skills (as the transfer of skills to a new situation of another subject); cognitive skills, as combining generalized and practical; from practical skills distinguish measuring, computing, design.

Keywords: a lesson; school education; individual work; research skills; educational environment; natural and mathematical disciplines; natural and mathematical competence.

П остановка проблеми. Швидкоплинність подій у сучасному інформаційному суспільствівимагасвідконкурентоспроможної молоді мобільностідій. Українська школа повинна забезпечити учнів такими компетентностями, які вони змогли б розширити у процесі самоосвіти протягом життя. Система педагогічних та науково-методичних заходів освіти спрямована на розвиток здобувачів освіти дослідницьких умінь засобами самостійної роботи. Самостійна робота як засіб розвитку умінь у процесі історичного розвитку освіти впливала на формування творчої роботи учнів й сприяла конгломерації компонентів дослідницьких умінь у загальній їх структурі. Самостійна робота учнів сприяла формуванню вміння логічно мислити та накопичувати досвід творчої діяльності, що, зі свого боку й визначило вектор сучасного розвитку дослідницьких умінь на уроках природничо-математичних дисциплін у закладах загальної середньої освіти України.

Аналіз останніх досліджень і публікацій. Погляд на формування та застосування самостійної роботи не залишився поза увагою й у сучасних науковців. Серед вітчизняних дослідників слід відзначити О. Палеху, яка визначила сутність поняття “самостійна позааудиторна робота" у британському науковому дискурсі; I. Свірепчука, який звернув увагу на модель самостійної роботи, визначивши такі компоненти: контакт викладача та студента формування уміння у різних середовищах, контроль за діяльністю; В. Броннікова вказує на організацію самостійноїроботиччнів; Л. Северинчук, акцентує увагу на ефективних формах та методах виховної роботи зі старшокласниками, серед яких є самостійна робота; натомість О. Молчанюк виокремлює самостійну роботу як засіб формування та розвитку креативності майбутніх учителів.

3-поміж зарубіжних авторів виокремлюємо Ю. Францеву, яка звертає увагу на умови організації самостійної роботи; А. Павлінов розглядає сучасні комп'ютерні технології як засіб самостійної роботи учнів; К. Іскіндірова визначає розвиток наукового географічного мислення та формування практичних навичок під час виконання самостійних робіт [4].

Формування дослідницьких умінь проходить складний шлях розвитку: I період (1958-1964) змістово-ідеологічний; II період (1965-1972) освітньо-політехнічний; III період (1973-1993) трансформаційно-дослідницький [1].

Мета статті: окреслити вплив самостійної роботи учнів на розвиток дослідницьких умінь учнів у період кінця 50 - початку 90-х рp. XX ст.

Виклад основного матеріалу. Самостійна робота завжди розглядалася методистами та дидактами як один із пріоритетних напрямів розвитку та формування умінь учнів. Так, Л. Виготський (1926) звертав увагу на взаємозв'язок навчання та розвитку. П. Блонський вивчав питання залежності засвоєння навчального матеріалу від характеру пам'яті та мислення (1935). Р. Мікельсон визначав самостійну роботу як виконання учнем завдання без допомоги вчителя, але під його наглядом $(1940)[5,28]$.

Перший досліджуваний період (1958-1964) змістово-ідеологічний характеризувався реформуванням школи.Створювалися виробничіучнівські бригади та зростала увага до навчально-матеріальної бази кабінетів природничо-математичних дисциплін. Частково уроки біології проводилися на навчальнодослідній ділянці. Приділялася увага екскурсіям на виробництво, але відсутньою була її чітка 


\section{ВПЛИВ САМОСТІЙНОЇ РОБОТИ УЧНІВ НА РОЗВИТОК ДОСЛІДНИЦЬКИХ УМІНЬ УЧНІВ НА УРОКАХ}

ПРИРОДНИЧО-МАТЕМАТИЧНИХ ДИСЦИПЛІН У ПЕРІОДКІНЦЯ 50 - ПОЧАТКУ 90-Х РР. ХХСТ.

організація. Практичний метод набував широкого поширення: демонстрація дослідів; виготовлення наочності; самостійне виконання лабораторних та практичних робіт; експеримент став складовою дослідницького методу. У 1962 р. 3'явилися перші публікації про диференційоване навчання у середній школі (праці Д. Мельникова, М. Гончаров), метою яких виступав розвиток індивідуальних особливостей та інтересів учнів на основі самостійної роботи. На уроках природничоматематичних дисциплін переважало використання методу фронтального експерименту. Самостійні роботи мали реконструктивний характер на уроках фізики та варіативний - на уроках математики. Зміст задач був доволі широкий: це і задачі, що пов'язані із життям, задачі, що мають неповні дані, та задачі практичного характеру. Приверталася увага до методики закладання досліду на уроках біології та сільського господарства. Відбувалася активізація самостійної роботи, але більшою мірою надавалася увага у цей період розвитку практичних умінь і навичок на уроках природничоматематичних дисциплін. Самостійна робота виступала засобом розвитку в учнів пізнавальних здібностей: спостереження, логічного мислення, пам'яті, уяви, творчої активності [2, 8].

Дослідницькі вміння у змістово-ідеологічному періоді тільки-но почали виокремлювалися на уроках, як такі: практичні уміння, політехнічні уміння, “уміння вчитися", загальні уміння сільськогосподарської праці, експериментальні уміння. Причому було зазначено їхню особливу рису - перехід одних умінь в інші.

Другий досліджуваний період (1965-1972) освітньо-політехнічний характеризувався завершенням переходу до загальної середньої освіти. Проблемне навчання було у пріоритеті. Дослідницько-практична робота у сільському господарстві набувала масового поширення; підвищувався методичний рівень викладання природничо-математичних дисциплін: використовувалися проблемні ситуації; виконувалисяпрактичні роботи за інструкцією; активізувалася пізнавальна діяльність; поширювалося диференційоване навчання; набували поширення міжпредметні зв'язки. Б. Ссипов зазначав, що “самостійну роботу не можна вважати тільки як самостійне виконання висновків учнем, оскільки вони грунтуються на матеріалі, що подав вчитель” [2, 15]. Посилювалася увага до агробіологічних основ сільськогосподарського дослідництва; відбувалося поєднання лабораторних і практичних робіт із сучасними обчислювальними приладами. В освітньому процесі запроваджувалася самостійна робота з підручниками, але водночас спостерігалося перенавантаження учнів. Дослідницький метод, у формі проблемних ситуацій, пошукової самостійної роботи, набував широкого використання в організації уроку, за рахунок чого реалізувався дослідницький підхід.

Крім того, відбувався й розвиток дослідницьких умінь у другому досліджуваному періоді: до умінь періоду змістово-ідеологічного додавалися загальнотрудові політехнічні вміння, інтелектуальні, навчальні, узагальненні, вперше почали виокремлюватися дослідницькі уміння як такі, але це тільки у форматі конгломерації практичних та інтелектуальних умінь.

Третій період (1973-1993) трансформаційнодослідницький охарактеризувався трансформацією низки умінь у дослідницькі. Для означеної досліджуваної доби характерні два субперіоди перший (1973 - 1983) “інтелектуальнопошуковий”, оскільки, у цей час набуває широкого застосування дослідницький підхід. Практичні вміння у своєму вигляді залишаються, але вони ж виступають і пігрунтям для інтелектуальних умінь, основу яких складають прийоми розумової діяльності й узагальнені вміння, що виходять на вищий щабель і стають міжпредметними основою, що є вмінням самостійно здобувати знання. Теорія поетапного формування розумових дій (поєднання практичної та пізнавальної діяльностей) набуває вдосконалення. Визначено рівні засвоєння знань: рівень засвоєння фактів, що відповідає елементарній пізнавальній активності учнів; другий рівень - розмірковування, коли учень обирає та застосовує прийоми мислення; третій рівень пізнавальної діяльності - учні самостійно визначають спосіб розв'язку завдань. Психологині Н. Менчинська та 3. Калмикова вказували, що “мислення учнів у процесі такого навчання $€$ глибоким, а дії $є$ самостійними” [3]. У цей період виокремлюються рівні сформованості вмінь, але класифікація їх ще відсутня.

Для другого субперіоду (1984-1993) “міжпредметно-дослідницький”, характерне відкриття профільних класів, що підвищувало якість природничо-математичної освіти, проводилася науково-дослідницька та експериментальна робота, що висвітлювалися у формі Малої академії наук. Реформа школи у цей період прагнула виконати соціальне замовлення: забезпечити учнів глибокими знаннями, уміннями застосовувати їх на практиці, формувати науковий світогляд, трудове виховання та політехнічну освіту учнів. Частина уроків проходила на навчально-дослідній ділянці. У навчальних програмах приділялася увага вмінням самостійно працювати з підручником. 
Для третього означеного періоду характерна трансформація практичних, інтелектуальних умінь та уміння навчальної праці у дослідницькі вміння. Відбувається спроба їх класифікації.

Натомість у змісті освіти відбуваються зміни у діяльнісному компоненті: додаються пошукова, творча та дослідницька діяльність. Серед форм навчання залишаються аудиторні уроки, а уроки на природі реалізуються у “зелений клас", де простежується екологічний аспект розвитку дослідницьких умінь. Серед методів певного вдосконалення набули різновиди самостійних робіт: алгоритмічні, варіативні, творчі, що спрямовані на пошукову роботу. Відбувається спроба класифікації методів, серед яких проблемно-пошуковий метод (відокремлюється від дослідницького); самостійно-пошуковий метод; дослідницький метод проходить шлях від пошукового до продуктивно-пізнавального. Дослідницькі вміння у період трансформації доповнюються міжпредметними вміннями (як перенесення умінь у нову ситуацію, або перенесення умінь в межі іншого предмета); пізнавальні уміння, як такі, що поєднують узагальнені та практичні; із практичних умінь виокремлюють вимірювальні, обчислювальні, конструкторські.

Висновки та перспективи подальших досліджень. Самостійна робота учнів мала вагомий вплив на розвиток дослідницьких умінь учнів на уроках природничо-математичних дисциплін у період кінця 50-х - початку 90-х рр. ХХ ст. Прийняття Закону СРСР "Про зміцнення зв'язку школи з життям і про подальший розвиток системи народної освіти в УРСР” визначило активізацію самостійної роботи в кінці 50 середини 60-х рр., що сприяла розвитку практичних умінь, та виступала засобом пізнавальних здібностей учнів. У кінці 60 - середини 70-х рр. $\mathrm{XX}$ ст. у зв'язку з переходом шкіл до загальної середньої освіти, поширення набуває пошукова самостійна робота, підгрунтям якої є уміння “самостійної роботи з підручником”, наслідком виступає розвиток інтелектуальних умінь. У кінці 70-х і до початку 90-х рр. означеного століття у зв'язку з прийняттям Закону "Про освіту" та реформуванням школи у середині 80-х р., пріоритетним напрямом виступає експериментальна робота, що має на меті самостійне здобуття знань. Всі означені засади сприяли поступовій трансформації різних видів умінь на уроках природничо-математичних дисциплін у дослідницькі.

Проведене дослідження не претендує на повне і всебічне розкриття всіх аспектів проблеми. Перспективними напрямами подальших наукових педагогічних студій вважаємо: характеристику реконструктивних, варіативних самостійних робіт; порівняльний аналіз самостійної роботи на уроках природничо-математичних дисциплін в Україні та зарубіжних країнах; аналіз використання різних типів самостійних робіт у системі шкільної освіти на сучасному етапі.

\section{ЛIТЕРАТУРА}

1. Галицька Н. Є. Дослідницькі уміння учнів у період освітніх реформ радянської школи. Педагогічні науки. Херсон: ХДУ, 2019. Вип. 87. С. 16-20.

2. Есипов Б. П. Самостоятельная работа учащихся на уроках. Москва: Учпедгиз, 1961. $239 \mathrm{c}$.

3. Зуева М. В. Развитие учащихся при обучении химии. Москва: Просвещение, 1978. 190 с.

4. Искиндирова К. К. Организация самостоятельной работы учащихся на уроках географи. Педагогическая наука и практика. 2013. №1 (1). C. 47-51. URL: https:// cyberleninka.ru/article/n/organizatsiya-samostoyatelnoyraboty-uchaschihsya-na-urokah-geografii (дата звернення: 28.08.2020).

5. Микельсон Р. М. О самостоятельной работе учащихся в процессе обучения. Москва: Учпедгиз, 1940. $96 \mathrm{c}$.

\section{REFERENCES}

1. Halytska, N. (2019). Doslidnytski uminnia uchniv u period osvitnikh reform radianskoi shkoly [Research skills of students during the educational reforms of the Soviet school]. Pedagogical sciences. Vol. 87. Kherson, pp. 16 20. [in Ukrainian].

2. Esipov, B. (1961). Samostoyatelnaya rabota uchashchihsya na urokah [Independent work of students in the classrom]. Moscow, p. 239. [in Russian].

3. Zueva, M. (1978). Razvitie uchashchihsya pri obuchenii himii [Student Development in Teaching Chemistry]. Moscow, p. 190. [in Russian].

4. Iskindirova, K. (2013). Organizaciya samostoyatelnoj raboty uchashchihsya na urokah geografii [Organization of students' independent work in geography lessons]. Pedagogical Science and Practice. No.1, St.Petersburg, pp. 47-51. URL: https://cyberleninka.ru/article/n/ organizatsiya-samostoyatelnoy-raboty-uchaschihsya-naurokah-geografii (accessed 28 Aug.2020). [in Russian].

5. Mikelson, R. (1940). O samostoyatelnoj rabote uchashchihsya $\mathrm{v}$ processe obucheniya [On the independent work of students in the learning]. Moscow, p. 96. [in Russian].

Стаття надійшла до редакції 10.08.2021

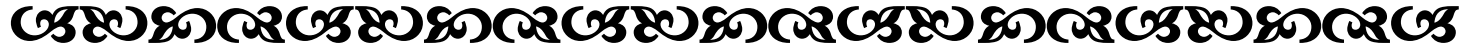

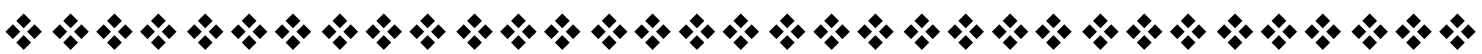

